\title{
Habitat and Landform Types Drive the Distribution of Carabid Beetles at High Altitudes
}

\author{
Mauro Gobbi ${ }^{1, *\left(\mathbb{D}, \text { Marco Armanini }^{2} \text {, Teresa Boscolo }\right.}{ }^{1}$, Roberta Chirichella ${ }^{3}{ }^{\circ}$, Valeria Lencioni ${ }^{1}{ }^{1}$, \\ Simone Ornaghi ${ }^{1}$ and Andrea Mustoni ${ }^{2}$ \\ 1 Section of Invertebrate Zoology and Hydrobiology, MUSE-Science Museum, Corso del Lavoro e della \\ Scienza 3, 38122 Trento, Italy; tb.entomologo@gmail.com (T.B.); Valeria.Lencioni@muse.it (V.L.); \\ simone.ornaghi@studenti.unimi.it (S.O.) \\ 2 Adamello-Brenta Natural Park, Via Nazionale 12, 38080 Strembo, Italy; marcoarmanini@pnab.it (M.A.); \\ andreamustoni@pnab.it (A.M.) \\ 3 Department of Veterinary Medicine, University of Sassari, Via Vienna 2, 07100 Sassari, Italy; \\ roberta.chirichella@gmail.com \\ * Correspondence: mauro.gobbi@muse.it
}

check for updates

Citation: Gobbi, M.; Armanini, M.; Boscolo, T.; Chirichella, R.; Lencioni, V.; Ornaghi, S.; Mustoni, A. Habitat and Landform Types Drive the Distribution of Carabid Beetles at High Altitudes. Diversity 2021, 13 , 142. https://doi.org/10.3390/ d13040142

Academic Editors: Luc Legal and Tibor Magura

Received: 25 February 2021

Accepted: 24 March 2021

Published: 26 March 2021

Publisher's Note: MDPI stays neutral with regard to jurisdictional claims in published maps and institutional affiliations.

Copyright: (c) 2021 by the authors. Licensee MDPI, Basel, Switzerland. This article is an open access article distributed under the terms and conditions of the Creative Commons Attribution (CC BY) license (https:// creativecommons.org/licenses/by/ $4.0 /)$.

\begin{abstract}
The high altitude mountain slopes of the Dolomites (Italian Alps) are characterized by great habitat and landform heterogeneities. In this paper, we investigated the effect of Nature 2000 habitat and landform types in driving the high altitude ground beetle (Carabidae) distribution in the Western Dolomites (Brenta group, Italy). We studied the carabid assemblages collected in 55 sampling points distributed in four Nature 2000 habitat types and four landform types located between 1860 and $2890 \mathrm{~m}$ above sea level (a.s.l.). Twenty-two species, half of them Alpine endemics, were sampled. Species richness and taxonomic distinctness did not show any significant difference among habitat types; conversely, these differences became significant when the landform type was considered. Total activity density and the frequency of brachypterous, endemic and predatory species showed significant differences between both habitat and landform types. Indicator species analysis identified twelve species linked to a specific habitat type and thirteen species linked to a specific landform type. Canonical correspondence analysis showed that altitude and vegetation cover drove the species distribution in each habitat and landform type while the aspect had a weak effect. Our results highlight the need for a geomorphological characterization of the sampling points when high altitude ground-dwelling arthropods are investigated.
\end{abstract}

Keywords: Alps; Dolomites; ground beetles; geomorphology; Nature 2000; rocky landforms; species distribution

\section{Introduction}

High altitude areas experience high landscape complexity driven not only by the occurrence of different habitat types but also by the different landforms on the mountain slopes that can increase the number of microhabitats available for colonization by plants and/or arthropods [1,2].

Carabid beetles (Coleoptera: Carabidae), along with springtails (Collembola), spiders (Arachnida: Araneae) and myriapods (Chilopoda and Diplopoda) are among the most common and most studied ground-dwelling arthropods living at high altitudes [2-5]. High mountain ecosystems especially above the treeline are mainly governed by climatic factors; therefore, changes in the occurrence of alpine species and in the composition of their assemblages are highly relevant for monitoring the impacts of climate change on the biotic component [2-6].

An increasing number of recent studies have investigated spatial and temporal patterns in species richness and species life history traits along altitudinal gradients [6-11]. However, information about the composition and distribution of species assemblages in 
the mosaic of habitat and rocky landform types available at a high altitude is still lacking for most of the mountain regions. This is probably due to the difficulties in reaching a few high altitude areas, in working under harsh environmental conditions and identifying in detail the different kind of landforms, specifically in alpine fellfields. However, our expectation is that recording both habitat and landform type will increase our understanding of carabid distribution in the mountains because landform diversity within each habitat type gives more detailed information about the availability of microhabitats determined by the geomorphological features of the slope.

Quantitative studies on the assemblage characteristics and habitat specificity of carabid beetles at high elevations (i.e., above the treeline) in the European Alps are available only for a few specific habitats such as glacial and periglacial landforms [2] and specific mountain groups such as Paneveggio-Pale di San Martino and Sarapiss (Eastern Dolomites, Italy) $[12,13]$.

As the mountain group of the Dolomites (Italian Alps) is one of the most spectacular examples of the result of geomorphological processes molding the mountain slopes [14], we selected it as the study area. Specifically, it offers a high geomorphological heterogeneity within each Nature 2000 habitat type. Nature 2000 is the largest coordinated network of protected areas in the world, aimed at protecting Europe's species and habitat diversity; more than 230 rare and characteristic habitat types, which must be protected, have been identified.

The aim of this study was to investigate the carabid beetle distribution in Nature 2000 habitats and rocky landforms located above the treeline of the Western Dolomites (Italian Alps). Specifically, we tested whether (1) carabid beetles' richness, taxonomic distinctness, activity density and percentage of high altitude specialists were associated with specific Nature 2000 habitats and landforms and (2) whether species occurrence was linked to specific habitat or landform types. Due to the great habitat and landform heterogeneity of the mountain slopes of the Dolomites [14] our expectation was to find a synergic effect of the Nature 2000 habitat and landform types in driving high altitude carabid beetle distribution.

Our study is the first to apply a geomorphological approach (i.e., the study of landform types) in addition to the habitat type approach to document carabid beetle distributions at high altitudes.

\section{Materials and Methods}

The Dolomites are a mountain range in the northern Italian Alps, which rise to above $3000 \mathrm{~m}$ above sea level (a.s.l.) and cover 141,903 ha. They are a UNESCO World Heritage Site and they are of international significance for geomorphology because they present a wide range of landforms related to erosion, tectonism and glaciation (https: / / whc.unesco.org/en/list/1237/, accessed on 1 March 2021).

A total of 11 plots were selected in the mountain group of the Brenta Dolomites (the westernmost mountain group of the Dolomites, Adamello-Brenta Natural Park) (Figure 1). Each plot was designed to represent the habitat and the landform heterogeneity available starting from the uppermost larch (Larix decida) forest (about $1900 \mathrm{~m}$ a.s.l.) to the Cima Grosté mountain peak (2901 m a.s.l.). Specifically, six plots were located along the northwest slope of the Brenta group (Vallesinella Valley, investigated in 2018) and five along the north-east slope (Tovel Valley, investigated in 2019).

In each plot (ca. $314 \mathrm{~m}^{2}$ ) five pitfall traps were placed $50 \mathrm{~m}$ apart to avoid spatial dependency. Each pitfall trap consisted of a plastic vessel (diameter $7 \mathrm{~cm}$, height $10 \mathrm{~cm}$ ) baited with a mixture of wine-vinegar and salt [2]. The traps were active over the entire snow-free season from early July to late September and collected and reset ca. every 20 days. 


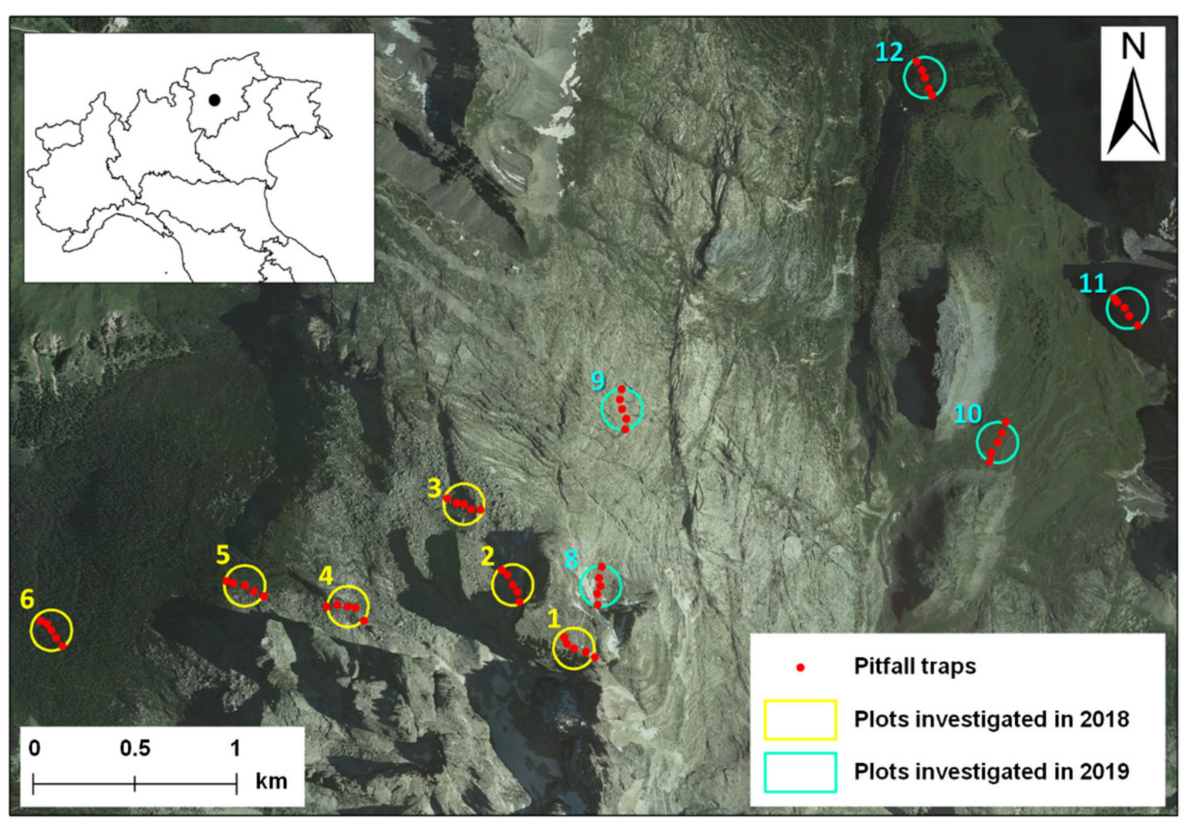

Figure 1. Study area located in the Adamello-Brenta Natural Park, Western Dolomites, Italian Alps $\left(46^{\circ} 11^{\prime} 1.94^{\prime \prime} \mathrm{N}, 10^{\circ} 54^{\prime} 2.41^{\prime \prime} \mathrm{E}\right.$; in black in the left panel) with the 11 investigated plots and the 55 sampling points (pitfall traps).

The following information was available for each trap: altitude ( $\mathrm{m}$ a.s.1.), vegetation cover (\%), Nature 2000 habitat code and landform type. These data were derived from the Digital Elevation Model (DEM) raster at a $10 \mathrm{~m}$ spatial resolution (PAT Geoportal: http: / /www.territorio.provincia.tn.it, accessed on 10 February 2021), the Habitat Nature 2000 code vector map (PAT Geoportal: http:/ / www.territorio.provincia.tn.it, accessed on 10 February 2021) and the landform type vector map (Geomorphologic database of BioMiti Project [15] in QGIS 3.10 [16].

A total of 55 sampling points (pitfall traps), ranging from ca. 1860 to ca. $2900 \mathrm{~m}$ a.s.l., were analyzed separately. For each trap the following information was obtained: species richness (i.e., the total number of species collected during the sampling season), abundance (i.e., the total number of individuals sampled), taxonomic distinctness (i.e., a measure that emphasizes the average taxonomic relatedness between species within a community $[17,18])$ and the percentage of species within the community sampled by the trap with the following species traits occurring simultaneously: brachypterous + endemic + predator (hereafter BEP species). BEP species are those with life history traits typical of the species living at high altitude; specifically, a low dispersal ability, restricted distributional range and specialized diet $[10,12,19]$.

Carabids were identified to the species level following Pesarini and Monzini [20,21] and are preserved in the entomological collection at the MUSE-Science Museum of Trento (Italy).

Traps at a higher altitude were kept active for a shorter period than those located at a lower altitude due to the shorter snow-free period. Therefore, to obtain comparable data among traps, the number of carabid individuals collected in each trap was transformed to an activity density (AD) [22] using the following formula: $\mathrm{AD}=$ (no. of individuals / (days of trap activity)). For each trap, the total activity density (TotalAD) was calculated by summing up the AD values of the different species recorded during each sampling session.

At first, the sampling points were grouped into six Nature 2000 habitat types:

- $\quad$ Code 4070 ( $\mathrm{n}=2$; bushes with Pinus mugo and Rhododendron hirsutum);

- $\quad$ Code 6170 ( $\mathrm{n}=11$; alpine and subalpine calcareous grasslands);

- $\quad$ Code 8120 ( $n=17$; calcareous and calcshist screes of the montane to alpine levels);

- $\quad$ Code 8210 ( $\mathrm{n}=12$; calcareous rocky slopes with chasmophytic vegetation); 
- $\quad$ Code 8240 ( $\mathrm{n}=3$; limestone pavements);

- Code 9420 ( $\mathrm{n}=10$; alpine Larix decidua and/or Pinus cembra forests) (https:/ / eunis. eea.europa.eu/habitats-annex1-browser.jsp, accessed on 17 January 2021).

As a few sampling points were located in the habitat types 4070 and 8240, we jointed them for affinity (i.e., vegetation cover $=100 \%$ ), respectively, to the habitat type 9420 and 8210 , respectively. Thus, four habitat groups were obtained: 6170; 8120; 8210-8240 and 9420-4070).

The sampling points were then also grouped into seven landform types:

- $\quad$ Active debris flow $(\mathrm{n}=2)$;

- $\quad$ Bedrock $(\mathrm{n}=14)$;

- $\quad$ Glacial deposit $(\mathrm{n}=1)$;

- $\quad$ Large rockslide deposit $(\mathrm{n}=10)$;

- $\quad$ Mature slope (vegetation cover $\geq 90 \% ; n=21$ );

- $\quad$ Rockslide deposit $(\mathrm{n}=1)$;

- Talus slope $(n=6)$.

As a few sampling points were located in the active debris flow, glacial deposit and rockslide deposit landform types we combined them for affinity with the talus slope (i.e., small-medium sized rock deposits) and large rockslide deposit landform types, respectively. Consequently, four landform types were considered: bedrock, large rockslide deposit, mature slope and talus slope. Thus, different landform types representing the geomorphological variability that could be found within a habitat type could be examined for each habitat type.

To compare the average species richness, total activity density, taxonomic distinctness and BEP species recorded in each Nature 2000 habitat and landform type we performed a Kruskal-Wallis test. This test was made possible by the fact that the traps set in each Nature 2000 habitat and landform type were spatially independent of each other; thus, the assumption of independence of the observations was satisfied [23,24]. When we obtained a significant difference among habitat types a Dunn's post-hoc test was performed.

To identify characteristic carabid species of each habitat and landform type, indicator species analysis (IndVal) [25] was used. The IndVal index for abundance data was used to quantify the association between each species and each habitat and landform. Once the highest associated habitat and landform were identified for each species, the association was assessed through a permutation test (number of permutations: 999). We then grouped the species in relation to their presence and total activity density for each of the habitat types considered.

To describe the patterns of species distribution in each landform type and their relationships with environmental variables, canonical correspondence analysis (CCA) was used [26]. Before running the analysis, the vegetation cover was $\arcsin \sqrt{ }(\mathrm{p} / 100)$ transformed, the altitude was natural $\log$ transformed and the aspect was $-\cos (\mathrm{x})$ transformed to normalize the distribution. To run the analysis, the species Harpalus solitaris was ruled out from the dataset because it was found in just one sampling point.

All of the analyses were run in PAST 4.05 [26].

\section{Results}

A total of 928 individuals belonging to 22 species were sampled (Table S1). Half of the sampled species were Alpine endemic and half of them were steno-endemic of the Dolomites (Table S1).

The average species richness and taxonomic distinctness did not show any significant differences among habitat types; conversely, these differences became significant when the landform type was considered (Table 1). The average total activity density and BEP species showed significant differences among both habitat and landform types (Table 1; Table S2; Figure 2). 
(a)

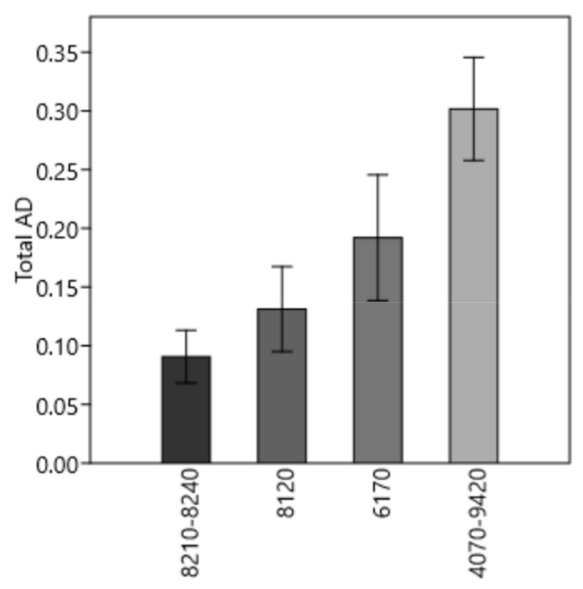

(c)

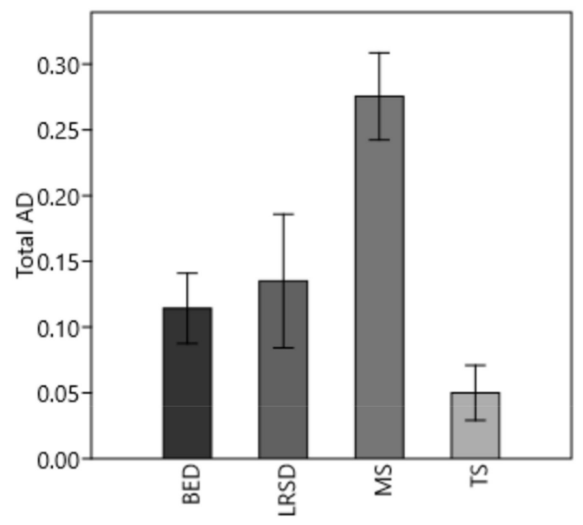

(e)

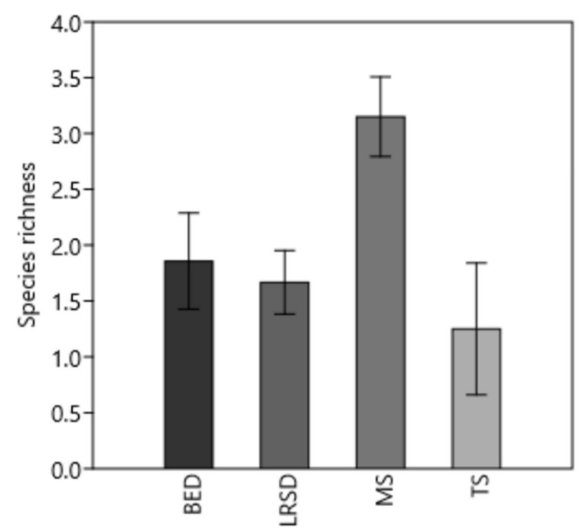

(b)

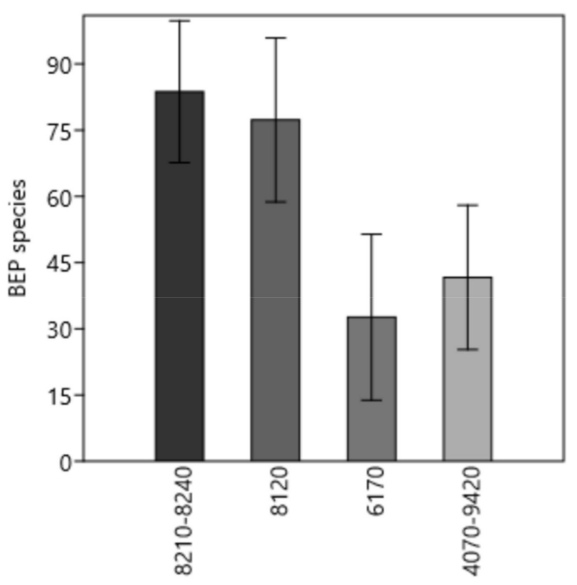

(d)

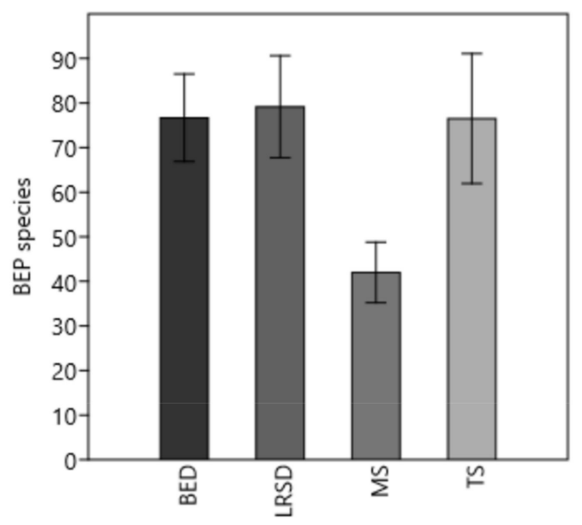

(f)

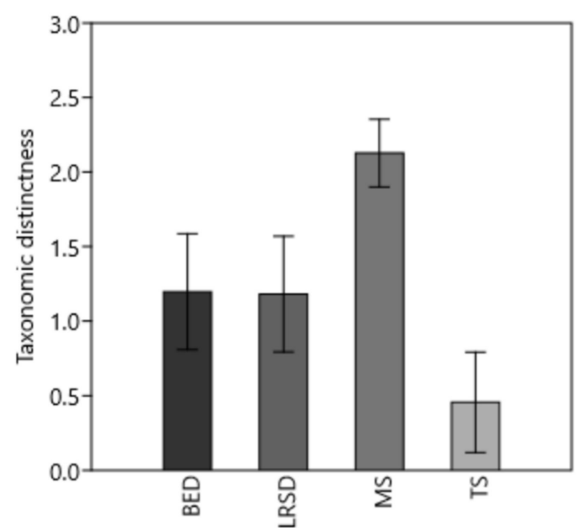

Figure 2. Average carabid species richness, taxonomic distinctness, total activity density and frequency of BEP species ( $y$-axis) in relation to the Nature 2000 habitat (6170 = alpine and subalpine calcareous grasslands; $8120=$ calcareous and calcshist screes of the montane to alpine levels; $8210-8240=$ limestone pavements and calcareous rocky slopes with chasmophytic vegetation; 9420-4070 = alpine Larix decidua and/or Pinus cembra forests and bushes with Pinus mugo and Rhododendron hirsutum); graphs (a,b) and landform types (BED = bedrock; LRSD = large rockslide deposit; MS = mature slope; TS = talus slope); graphs (c-f). The whisker intervals represent a $95 \%$ confidence interval based on the standard error. Only the results in which we obtained a significant difference $(p<0.05)$ among habitat and landform type are represented (for more information see Table S2). 
Table 1. Results of the Kruskal-Wallis test (values in the columns: $\mathrm{X}^{2}$ and $p$-value).

\begin{tabular}{ccc}
\hline Variables & Habitat Type & Landform Type \\
\hline Species richness & $6.3 ; 0.09$ & $12.3 ; 0.005^{*}$ \\
Activity density & $14.2 ; 0.003 *$ & $19.2 ; 0.0002 *$ \\
Taxonomic distinctness & $5.8 ; 0.09$ & $8.7 ; 0.023^{*}$ \\
BEP species & $13.4 ; 0.002 *$ & $10.9 ; 0.007^{*}$ \\
\hline
\end{tabular}

* significant difference $(p<0.05)$. BEP $=$ brachypterous + endemic + predator.

The most abundant species was Pterostichus multipunctatus (sum of AD recorded in all traps in which the carabid was collected $=4.42$ ) followed by Nebria germari (sum of AD recorded in all traps in which the carabid was collected $=1.85$ ). The most frequent species resulted Pterostichus multipunctatus ( $47.3 \%$ of occurrence) followed by Carabus adamellicola (36.4\% of occurrence) and Nebria germari (23.6\% of occurrence); the rest of the species were below $10 \%$ occurrence.

According to the indicator species analysis, 12 species were significantly linked to a specific Nature 2000 habitat type: Nebria germari was linked to calcareous rocky slopes with chasmophytic vegetation; Carabus adamellicola to calcareous scree slopes; Calathus melanocephalus, Carabus convexus, Cymindis vaporariorum, Harpalus latus and $H$. solitaris to calcareous grasslands and Calathus micropterus, Cychrus attenuatus, Leistus nitidus, Pterostichus multipunctatus and P. unctulatus to larch and dwarf pine formations (Table S3).

The graphs for the species assemblages sampled in each Nature 2000 habitat type (Figure 3) show differences in the composition of assemblages found in highly vegetated habitats (code 6170 and 4070-9420) compared with habitats with patchy vegetation and those completely unvegetated (code 8120 and 8210-8240). Pterostichus multipunctatus was found to be the species with the highest total activity density (dominant species) exclusively in calcareous grasslands and larch and dwarf pine formations while Nebria germari was dominant in calcareous scree slopes with chasmophytic vegetation. All of the habitat types apart from calcareous scree slopes had species assemblages characterized by one dominant species followed by several species with low and similar total activity density values.

According to the indicator species analysis result, 13 species were significantly linked to a specific landform type: Duvalius nambinensis and Oreonebria castanea to the bedrock landform type; Carabus adamellicola and Carabus creutzeri to large rockslide deposits; Calathus melanocephalus, C. micropterus, Carabus convexus, Cychrus attenuatus, Cymindis vaporariorum, Harpalus latus, Pterostichus multipunctatus and P. unctulatus to mature slopes and Abax pilleri to talus slopes.

The CCA analysis on species distribution in relation to the Nature 2000 habitat type, landform type and the altitude, vegetation cover and aspect variables revealed that most of the variance was explained by Axis $1(90.5 \%)$ while Axis 2 explained only $9.5 \%$ of the total variance (Table 2, Figure 4). As shown in Figure 4, Axis 1 was mainly explained by the negative correlation among altitude and vegetation cover while Axis 2 was weakly explained by aspect. This result was clearly visible in the species distribution along Axis 1 ; two groups were visible with the former clustered in the quadrants one and two of the CCA and the latter in the quadrants three and four. Specifically, the occurrence of the species Nebria germari, Oreonebria castanea, Trechus sinuatus and Duvalius nambinensis was shown as linked to the calcareous scree slopes with chasmophytic vegetation, talus slopes and large rockslide deposits habitats located at the highest altitude and with the lowest vegetation cover. Carabus creutzeri and Carabus adamellicola were linked to the calcareous scree slopes with chasmophytic vegetation, calcareous grasslands and with bedrock and large rockslide deposit habitats located at an intermediate altitude and with an intermediate level of vegetation cover. The rest of the species (quadrants 3 and 4) were linked to mature slopes and talus slopes located at the lowest altitude and with the highest level of vegetation cover. 

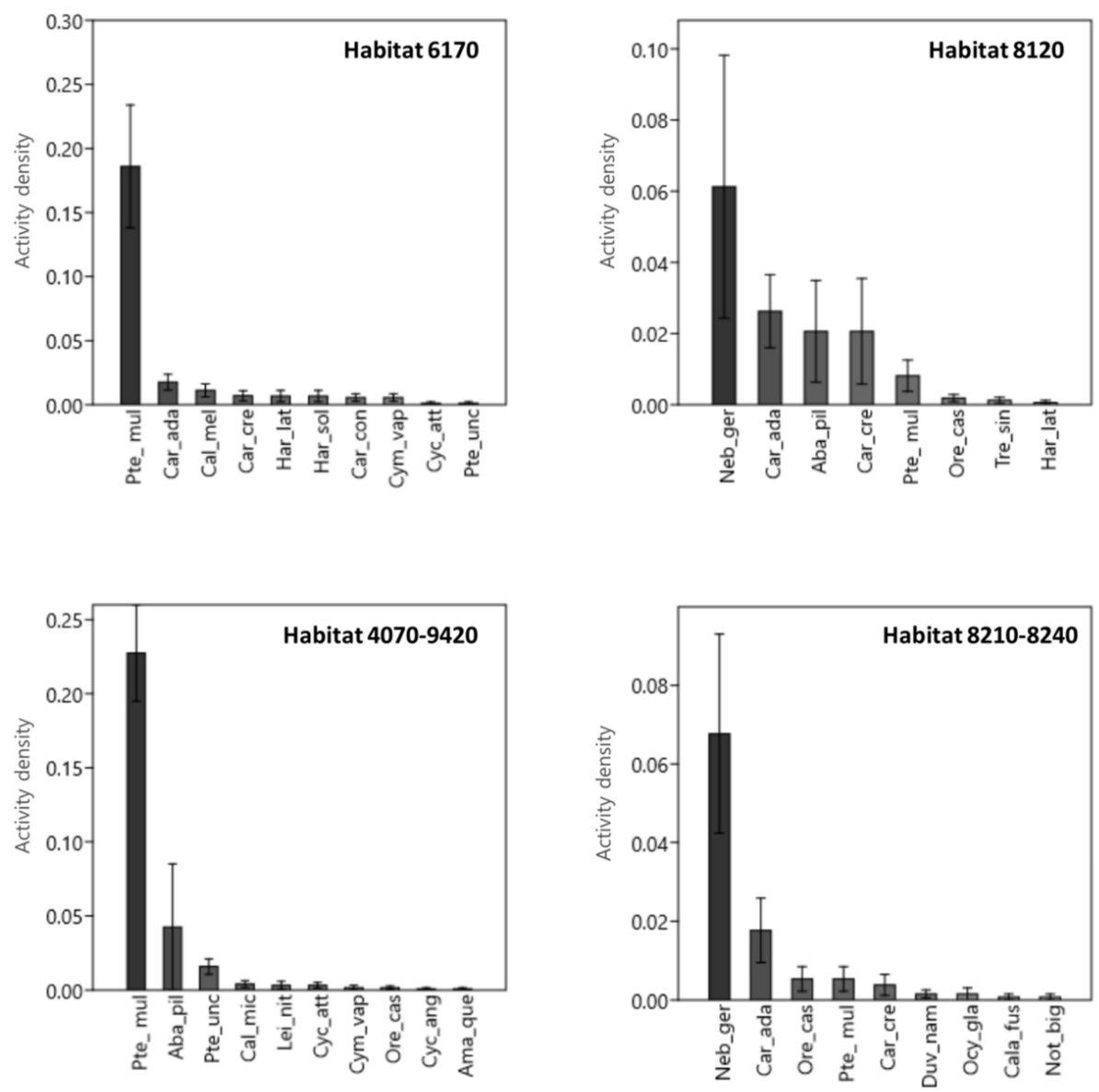

Figure 3. Average species activity density ( $y$-axis) recorded in each of the Nature 2000 habitat types. Habitat types: $6170=$ alpine and subalpine calcareous grasslands; $8120=$ calcareous and calcshist screes of the montane to alpine levels; $8210-8240=$ limestone pavements and calcareous rocky slopes with chasmophytic vegetation; 9420-4070 = alpine Larix decidua and/or Pinus cembra forests and bushes with Pinus mugo and Rhododendron hirsutum. The whisker intervals represent a 95\% confidence interval based on the standard error. Species abbreviation refers to Table S1.

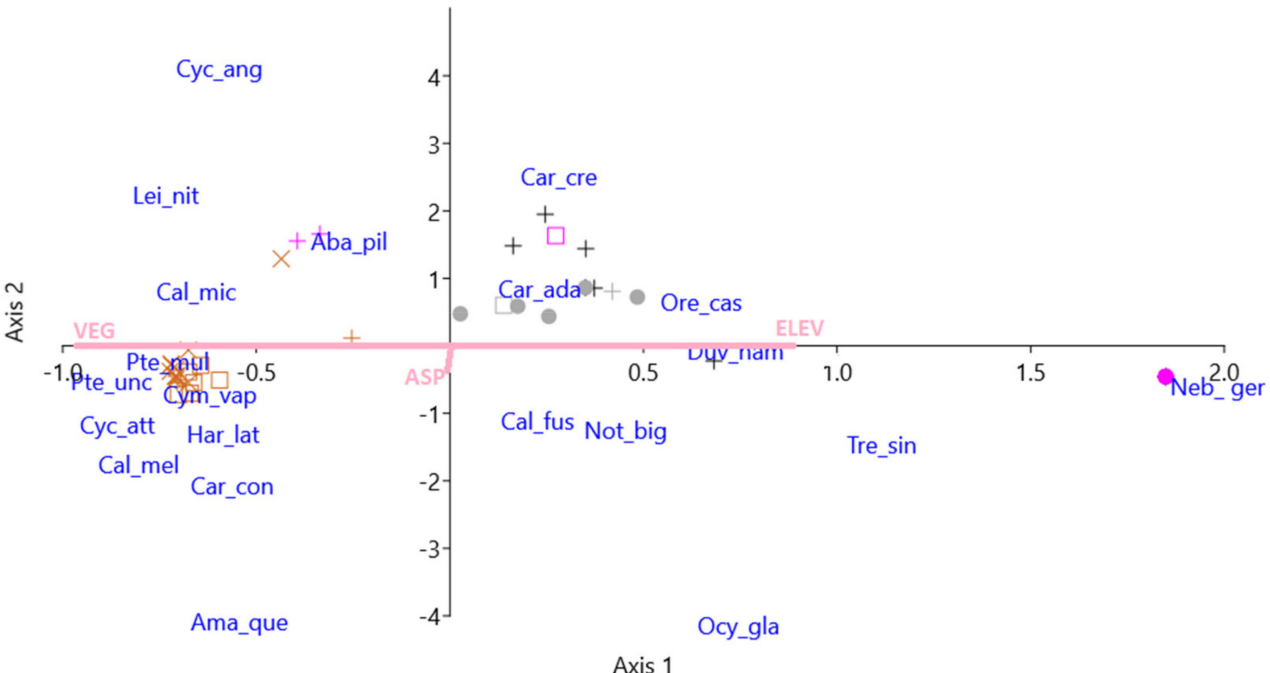

Figure 4. CCA triplot of the distribution of carabid species in relation to the altitude (Alt), vegetation cover (Veg) and aspect (Asp) (vectors in pink). Nature 2000 habitat types are represented as follows: $8210-8240=$ black dot; $8120=$ plus; $6170=$ square; $4070-9420=\mathrm{X}$. Landform types are represented as follows: bedrock = dark gray; large rockslide deposit = black; talus slope $=$ fuchsia; mature slope = light brown. Species abbreviation refers to Table S1. 
Table 2. Canonical correspondence analysis (CCA) scores of the environmental variables and percentage of explained variance.

\begin{tabular}{ccc}
\hline CCA & Axis 1 & Axis 2 \\
\hline Elevation & 0.882 & -0.025 \\
Aspect & -0.006 & -0.360 \\
Vegetation cover & -0.965 & 0.001 \\
Eigenvalue & 0.912 & 0.096 \\
\% of explained variance & 90.5 & 9.5 \\
$p$-value (999 permutation) & $0.001^{*}$ & $0.016^{*}$ \\
\hline
\end{tabular}

* significant values, $p<0.05$.

\section{Discussion}

Our work was one of the first attempts to simultaneously investigate the effects of habitat and landform types on the distribution of carabid species at a high altitude.

Twenty-two ground-dwelling carabid species were sampled at a high altitude in the Brenta Dolomites.

Interestingly, species richness and taxonomic distinctness changed significantly in relation to landform type but not to habitat type. Specifically, mature slopes had the highest species richness and the highest phylogenetically distant assemblages. The activity density reached the highest values on larch and dwarf pine formations and on mature slopes or on slopes that were stable or least affected by gravitational processes (e.g., rock falls). This finding partially supports the pattern of species richness and activity density observed in the Eastern Dolomites by Pizzolotto et al. [12].

A weak positive correlation between altitude and the frequency of low dispersal (brachypterous), predatory and endemic species was found in the Alps [12]. Our data support the evidence provided by Chamberlain et al. [10] about the role of habitat type as an important driver of the occurrence of species traits. We also demonstrated the role of the landform type in the frequency of BEP species. Specifically, we demonstrated that endemic, poorly-dispersing and predatory species prefer calcareous scree slopes with chasmophytic vegetation and specifically large rockslide deposits, bedrocks and scree slope landforms. The Brenta Dolomites are a peripheral mountain chain of the Italian Alps and compared with the inner massifs [12] they have a higher frequency of species with a low dispersal capability (i.e., steno-endemic species such as Carabus adamellicola, Duvalius nambinensis) and a specialized diet (e.g., Carabus creutzeri, Cychrus spp. (snail feeder), Notiophilus biguttatus (springtails)).

High altitude habitats of the Brenta Dolomites were dominated by three species: Nebria germari, Carabus adamellicola and Pterostichus multipunctatus. Among them, only Nebria germari is also present in the Eastern Dolomites [27]. Currently, N. germari does not seem to occur below $2550 \mathrm{~m}$ a.s.l.; an altitudinal shift due to the climate warming confirmed throughout the Dolomites [28]. Carabus adamellicola is a steno-endemic species of the Adamello-Brenta mountain group, vicariant of $C$. bertolinii and C. alpestris of the Central-Eastern Dolomites [12], but unlike these species it was sampled from the alpine calcareous grasslands to substrates with low or patchy vegetation.

The indicator species analysis found that both Nebria germari and Carabus adamellicola were indicator species of calcareous scree slopes with chasmophytic vegetation. Nebria germari was not found to be an indicator of any specific landform within these habitat types. In fact, it can be found in a wider range of landform types such as glacier fronts, moraines along the glacier forelands of the Western Dolomites $[19,28]$ and other fellfields. Conversely, C. adamellicola is significantly linked to large rockslide deposits. The presence of these species in high altitude areas can be explained by the local availability of humidity determined by long-lasting snow cover and the microthermal conditions of the fellfield (average annual humidity and temperature of the six plots where the species were found (plot n. 1, 2, 3, 4, 6 and 9, see. Table S1): relative humidity $=92.6 \pm 7.8 \%$; average temperature $=2.7 \pm 1.4{ }^{\circ} \mathrm{C}$, unpublished data). Pterostichus multipunctatus, Calathus micropterus, 
Cychrus attenuatus, Leistus nitidus and Pterostichus unctulatus are significantly linked to larch and dwarf pine formations and to the mature slope landform type. Moreover, all of these species except $P$. multipunctatus well represent the typical forest assemblages of the Italian Alps. Pterostichus multipunctatus can be considered an ecological vicariant of $P$. morio (Eastern Dolomites) and, like P. morio [27], is more common in alpine grasslands located on stable slopes.

The indicator species analysis selected Calathus melanocephalus, Carabus convexus, Cymindis vaporariorum, Harpalus latus and $\mathrm{H}$. solitaris as species linked to calcareous grasslands. These species are typical of xeric areas [27-29], specifically those that experience the periodical presence of grazing animals (e.g., cows, goats and sheep), which is a quite common practice on the European Alps.

The CCA analysis confirmed the effect of altitude and vegetation cover in driving the species distribution in each habitat and landform type. Specifically, Nebria germari, Trechus sinuatus and Duvalius nambinensis were shown as species linked to talus slopes and large rockslide deposits located at a high altitude (average value $=2600 \mathrm{~m}$ a.s.l.) with a low percentage of vegetation cover (average value $=6 \%$ ).

Carabus creutzeri and C. adamellicola distribution was linked to large rockslide deposits and bedrock located at lower altitudes (average value $=2400 \mathrm{~m}$ a.s.l.) and with greater vegetation cover (average value $=30 \%$ ). Carabus creutzeri is a forest species [12] but our data support the findings by Brandmayr and Zetto Brandmayr [27] of its presence also in open areas at high altitude, specifically in Alpine areas with a high level of annual rainfall such as the Brenta Dolomites (average annual rainfall = ca. $1400 \mathrm{~mm}$; www.climatrentino.it, accessed on 17 January 2021).

\section{Conclusions}

Geomorphological diversity (also known as geodiversity) supports a diversity of habitats across a wide range of temporal and spatial scales. It has an important ecological value in supporting biodiversity and ecosystem functioning and it is key element in protected areas [30].

Our data showed that the distribution of carabid beetle species at high altitudes in the Brenta Dolomites area of the Adamello-Brenta Natural Park was driven by two key elements of its mountain slope physiography: habitat and landform type.

The classification approach of the Nature 2000 habitats proved useful for identifying indicator species but geomorphological heterogeneity (landform type) within each habitat type was an additional instrument able to give information about microhabitat preferences. On the basis of the obtained results, we recommend applying a detailed geomorphological approach to studies aimed at investigating the distribution of grounddwelling arthropods in high altitude areas. We expect that the distribution of other epigeic taxa (e.g., Chilopoda [31]) may also be affected by the geomorphological features of the mountain slopes.

Supplementary Materials: The following are available online at https:/ /www.mdpi.com/article/10 .3390/d13040142/s1 Table S1: List of the sampled points with information about the collected species, Elevation (m a.s.l.), Aspect $\left({ }^{\circ}\right)$, vegetation cover $(\%)$, Nature 2000 habitat code and landform type. For each species, information about wing morphology, chorology and diet are provided. Table S2: Dunn's post-hoc values showing the significant differences found for species richness, taxonomic distinctness, activity density and BEP species among the analyzed habitat and landform types. Table S3: Results of the indicator species analysis (IndVal). Significant relationships are reported in bold.

Author Contributions: Conceptualization, A.M., R.C. and M.A.; methodology, M.G.; field activity, A.M.; M.A. and R.C., statistical analysis, M.G.; species sorting and identification, T.B., S.O. and M.G.; writing-original draft preparation, M.G.; project administration, A.M. and V.L.; funding acquisition, A.M., M.G. and V.L. All authors have read and agreed to the published version of the manuscript.

Funding: This research was co-funded by Adamello-Brenta Natural Park and Province Autonomous of Trento. 
Institutional Review Board Statement: The permission to collect carabid beetles was provided by the Director of the Adamello Brenta Natural Park (Agreement number: MTSN-0011014-07/12/2018A-Allegato Utente 1 (A01)).

Informed Consent Statement: Not applicable.

Data Availability Statement: The dataset used in this paper is publicly available in the Supplementary Materials.

Acknowledgments: We are grateful to the staff of the Parco Naturale Adamello-Brenta and to Ivan Petri, for their help during the field activity and to Alessandra Franceschini for her help in managing the carabid beetle collection. David Kavanaugh (California Academy of Science, USA) revised the English and provided useful suggestions.

Conflicts of Interest: The authors declare no conflict of interest.

\section{References}

1. Gilardelli, F.; Sgorbati, S.; Armiraglio, S.; Citterio, S.; Gentili, R. Ecological Filtering and Plant Traits Variation across Quarry Geomorphological Surfaces: Implication for Restoration. Environ. Manag. 2015, 55, 1147-1159. [CrossRef] [PubMed]

2. Gobbi, M. Global warning: Challenges, threats and opportunities for ground beetles (Coleoptera: Carabidae) in high altitude habitats. Acta Zoöl. Acad. Sci. Hung. 2020, 66, 5-20. [CrossRef]

3. Beron, P. High-mountain Isopoda Oniscidea, Arachnida and Myriapoda in the Old World. Bureschiana, Sofia, Pensoft \& Nat. Mus. Natur. Hist. Sofia 2008, 1, 556.

4. Beron, P. High-altitude: Isopoda, Arachnida and Myriapoda in the New World. Sofia, Pensoft \& Nat. Mus. Natur. Hist. Sofia 2008, 2,556 .

5. Hågvar, S.; Gobbi, M.; Kaufmann, R.; Ingimarsdóttir, M.; Caccianiga, M.; Valle, B.; Pantini, P.; Fanciulli, P.P.; Vater, A. Ecosystem Birth Near Melting Glaciers: A Review on the Pioneer Role of Ground-Dwelling Arthropods. Insects 2020, 11, 644. [CrossRef] [PubMed]

6. Viterbi, R.; Cerrato, C.; Bassano, B.; Bionda, R.; Von Hardenberg, A.; Provenzale, A.; Bogliani, G. Patterns of biodiversity in the northwestern Italian Alps: A multi-taxa approach. Community Ecol. 2013, 14, 18-30. [CrossRef]

7. Staunton, K.M.; Nakamura, A.; Burwell, C.J.; Robson, S.K.A.; Williams, S.E. Elevational Distribution of Flightless Ground Beetles in the Tropical Rainforests of North-Eastern Australia. PLoS ONE 2016, 11, e0155826. [CrossRef] [PubMed]

8. Hiramatsu, S.; Usio, N. Assemblage Characteristics and Habitat Specificity of Carabid Beetles in a Japanese Alpine-Subalpine Zone. Psyche A J. Èntomol. 2018, 2018, 1-15. [CrossRef]

9. Baranovská, E.; Tajovský, K.; Knapp, M. Changes in the Body Size of Carabid Beetles along Elevational Gradients: A Multispecies Study of Between- and Within-Population Variation. Environ. Ėntomol. 2019, 48, 583-591. [CrossRef]

10. Chamberlain, D.; Gobbi, M.; Negro, M.; Caprio, E.; Palestrini, C.; Pedrotti, L.; Brandmayr, P.; Pizzolotto, R.; Rolando, A. Traitmodulated decline of carabid beetle occurrence along elevational gradients across the European Alps. J. Biogeogr. 2020, 47, 1030-1040. [CrossRef]

11. Ouisse, T.; Day, E.; Laville, L.; Hendrickx, F.; Convey, P.; Renault, D. Effects of elevational range shift on the morphology and physiology of a carabid beetle invading the sub-Antarctic Kerguelen Islands. Sci. Rep. 2020, 10, 1-12. [CrossRef] [PubMed]

12. Pizzolotto, R. Habitat diversity analysis along an altitudinal sequence of alpine habitats: The Carabid beetle assemblages as a study model. Period. Biol. 2016, 118, 241-254. [CrossRef]

13. Bernasconi, M.G.; Borgatti, M.S.; Tognetti, M.; Valle, B.; Caccianiga, M.; Casarotto, C.; Ballarin, F.; Gobbi, M. Checklist ragionata della flora e degli artropodi (Coleoptera: Carabidae e Arachnida: Araneae) dei ghiacciai Centrale e Occidentale del Sorapiss (Dolomiti d'Ampezzo). Frammenti Conoscere e Tutelare la Natura Bellunese 2019, 9, $49-65$.

14. Soldati, M. Dolomites: The Spectacular Landscape of the 'Pale Mountains'. In Geomorphological Landscapes of the World; Metzler, J.B., Ed.; Springer: Dordrecht, The Netherlands, 2009; pp. 191-199.

15. Zanoner, T.; Seppi, R.; Carton, A. Database Geomorfologico del Progetto BioMiti; Tecnical Report and Vector Data; Adamello Brenta Natural Park: Strembo, Italy, 2019.

16. QGIS Development Team. QGIS Geographic Information System. Available online: http://qgis.osgeo.org,2020 (accessed on 10 February 2021).

17. Clarke, K.R.; Warwick, R.M.; Pienkowski, M.W.; Watkinson, A.R.; Kerby, G. A taxonomic distinctness index and its statistical properties. J. Appl. Ecol. 1998, 35, 523-531. [CrossRef]

18. Gobbi, M.; Lencioni, V. Do carabids (Coleoptera: Carabidae) and chironomids (Diptera: Chironomidae) exhibit similar diversity and distributional patterns along a spatio-temporal gradient on a glacier foreland? J. Limnol. 2018, 77, 187-195. [CrossRef]

19. Gobbi, M.; Ballarin, F.; Brambilla, M.; Compostella, C.; Isaia, M.; Losapio, G.; Maffioletti, C.; Seppi, R.; Tampucci, D.; Caccianiga, M. Life in harsh environments: Carabid and spider trait types and functional diversity on a debris-covered glacier and along its foreland. Ecol. Èntomol. 2017, 42, 838-848. [CrossRef]

20. Pesarini, C.; Monzini, V. Insetti della fauna italiana. Coleotteri Carabidi I. Società Italiana di Scienze Naturali 2010, $100,152$.

21. Pesarini, C.; Monzini, V. Insetti della fauna italiana. Coleotteri Carabidi II. Società Italiana di Scienze Naturali 2011, $101,144$. 
22. Brandmayr, P.; Brandmayr, T.Z.; Pizzolotto, R. I Coleotteri Carabidi per la valutazione ambientale e la conservazione delle biodiversità. In Manuale Operativo, Agenzia per la Protezione dell'Ambiente e per i Servizi Tecnici; IGER: Rome, Italy, 2005; Volume 34, p. 240.

23. Wayne, W.D. Kruskal-Wallis one-way analysis of variance by ranks. In Applied Nonparametric Statistics, 2nd ed.; Wayne, W.D., Ed.; Duxbury Classic Series: Boston, MA, USA, 1990; pp. 226-234.

24. Theodorsson-Norheim, E. Kruskal-Wallis test: BASIC computer program to perform nonparametric one-way analysis of variance and multiple comparisons on ranks of several independent samples. Comput. Methods Programs Biomed. 1986, 23, 57-62. [CrossRef]

25. Dufrene, M.; Legendre, P. Species assemblages and indicator species: The need for a flexible asymmetrical approach. Ecol. Monogr. 1997, 67, 345-366. [CrossRef]

26. Hammer, Ø.; Harper, D.A.T.; Ryan, P.D. PAST: Paleontological statistics software package for education and data analysis. Palaeontol. Electron. 2001, 4, 9.

27. Brandmayr, P.; Brandmayr, T.Z. Comunità a coleotteri carabidi delle Dolomiti Sudorientali e delle Prealpi Carniche. Zoocenosi e Paesaggio-I Le Dolomiti, Val di Fiemme-Pale di S. Martino (ed. by P. Brandmayr ). Studi Trent. Sci. Nat. Acta Biol. 1988, 64, 125-250.

28. Valle, B.; Ambrosini, R.; Caccianiga, M.; Gobbi, M. Ecology of the cold-adapted species Nebria germari (Coleoptera: Carabidae): The role of supraglacial stony debris as refugium during the current interglacial period. Acta Zoöl. Acad. Sci. Hung. 2020, 66, 199-220. [CrossRef]

29. Gobbi, M.; Fontaneto, D.; Bragalanti, N.; Pedrotti, L.; Lencioni, V. Carabid beetle (Coleoptera: Carabidae) richness and functional traits in relation to differently managed grasslands in the Alps. Annales de la Société entomologique de France (N.S.) 2015, 51, 52-59. [CrossRef]

30. Crofts, R. Linking geoconservation with biodiversity conservation in protected areas. Int. J. Geoherit. Park. 2019, 7, $211-217$. [CrossRef]

31. Gobbi, M.; Caccianiga, M.; Compostella, C.; Zapparoli, M. Centipede assemblages (Chilopoda) in high-altitude landforms of the Central-Eastern Italian Alps: Diversity and abundance. Rendiconti Lincei Scienze Fisiche e Naturali 2020, 31, 1071-1087. [CrossRef] 